\title{
COMMENTS
}

\section{MANIPULATION OF COMMODITY FUTURES PRICES- THE GREAT WESTERN CASE}

The recent case of Great Western Food Distributors ข. Benson ${ }^{1}$ marked the first time that an order of the Judicial Officer of the Secretary of Agriculture ${ }^{2}$ suspending a respondent's trading privileges on all contract markets for violation of the Commodity Exchange Act' ${ }^{3}$ anti-corner provision ${ }^{4}$ was sustained on review by a Court of Appeals. In order to understand the court's decision and reasoning it is necessary to examine the general theory and practice of manipulation on commodity exchanges.

\section{I}

A futures transaction is a standardized contract made on or subject to the rules of a board of trade in which the seller or "short" agrees to sell and deliver a specified amount of a commodity in a certain month to the purchaser or "long" who agrees to accept and pay on delivery. ${ }^{5}$ Although the long can insist on taking and the short on making delivery-which is effected by the passage of warehouse receipts - upwards of $99 \%$ of all futures contracts are liquidated by purchases or sales of offsetting contracts in which equal long and short positions are cancelled

1201 F. 2 d 476 (C.A. 7th, 1953), cert. denied 345 U.S. 997 (1953); cf. General Foods Corp. v. Brannan, 170 F. 2 d 220 (C.A. 7th, 1948), rev'g 6 A.D. 288 (1947). See note 23 infra.

2 In re Great Western Distributors, Inc., et al., 10 A.D. 783 (1951). The Judicial Officer acts for the Secretary of Agriculture pursuant to authority delegated (10 F.R. 13,769) under the Act of April 4, 1940, c. 75, 54 Stat. 82, 5 U.S.C.A. $\$ 516 \mathrm{c}$ (1952).

349 Stat. 1491 (1936), 52 Stat. 205 (1938), 54 Stat. 1059 (1940), 61 Stat. 941 (1947), 62 Stat. 992 (1948), as amended, 7 U.S.C.A. $\$ 1-17$ (a) (1952), amending the Grain Futures Act, 42 Stat. 998 (1922).

4 Section 6(b), 7 U.S.C.A. $\$ 9$ (1952) authorizes the Secretary of Agriculture to suspend the trading privileges of a person who "is violating or has violated any of the provisions of this Act ... or has manipulated or is attempting to manipulate..." and it is a violation of Section 9,7 U.S.C.A. 13 (1952), which imposes criminal sanctions, to "manipulate or attempt to manipulate the price of any commodity in interstate commerce, or for future delivery on or subject to the rules of any board of trade, or who shall corner or attempt to corner any such commodity. ..." That violations of Section 9 such as cornering were to be incorporated into Section 6(b) and thus be subject to the regulatory provisions of the Act seems certain from the legislative history. See explanation in 80 Cong. Rec. 6160, 74th Cong., 1st Sess. (1936), Cf. Wallace v. Cutten, 298 U.S. 229 (1936), which precipitated amendment of the Grain Futures Act.

5 The most recent general work on the subject of futures trading is Baer and Saxon, Commodity Exchanges and Futures Trading (1949), which seems to over-emphasize the role of the exchanges as being vital to a "free economy" and to under-emphasize the limitations and abuses of futures trading. See note 12 infra, for a collection of recent articles concerned with the limitations and abuses. See generally, Hoffman, Futures Trading Upon the Organized Commodity Markets in the United States (1932); Federal Regulation of Commodity Futures Trading, 60 Yale L.J. 822 (1951). 
against each other. ${ }^{6}$ The reason is that most traders in futures, both speculators and hedgers, are not interested in making or taking delivery on their futures contracts, but rather in profiting or protecting themselves, respectively, from the movement of prices. ${ }^{7}$

The technical conditions which make planned manipulation of prices and the acquisition of control easier in futures than in the cash market are this state of mind of traders, ${ }^{8}$ and the possibility of their being forced to make or take delivery in a limited time on a particular market. If the possibility of taking advantage of these conditions were neutralized, delivery on futures contracts would be merely an alternative use for the commodity which would command no premium or discount compared with other normal movements into the channels of storage, processing, and consumption. ${ }^{9} \mathrm{It}$ is this same possibility of delivery, however, which preserves the generally parallel relation between futures and cash prices, ${ }^{10}$ enabling the futures markets to function as a commodity price quotation service and hedging medium for the reduction of risks in the marketing of agricultural commodities. ${ }^{11}$

- Shepherd, Marketing Farm Products 123 (1936); Hoffman, Grain Prices and the Futures Market 24 (USDA, Tech. Bull. No. 747, 1941); Hoffman, Future Trading Upon the Organized Commodity Markets in the United States, 106, 107 (1932). For recent statistics, see Commodity Exchange Authority, Commodity Futures Statistics, July 1946-June 1947, Table 3, at 13, and Table 10, at 30 (April, 1948); July 1947-June 1948, Table 3, at 10, and Table 13, at 37 (November, 1948); July 1948-June 1949, Table 3, at 10, and Table 14, at 36 (January, 1950).

'Irwin, Middleman's Accumulations and Expectations of Marketing Farm Products, 29 Jour. of Farm Econ. 848, 857 (1947). For a recent discussion which casts serious doubt on the validity of the traditional dichotomy between "hedging" and "speculation," see Working, Futures Trading and Hedging, 43 Am. Econ. Rev. 314 (1953).

- Hoffman, Future Trading Upon the Organized Commodity Markets in the United States 314-18 (1932); Prevention of Commodity Futures Manipulation under the Commodity Exchange Act, 54 Harv. L. Rev. 1373, 1375 (1941). See note 95 infra.

- 7 Federal Trade Commission Report on the Grain Trade 219 (1926) (hereinafter cited as FTC Report).

10 For general elementary discussions of the relation between cash and futures prices see Hoffman, Futures Trading Upon the Organized Commodity Markets in the United States, 275, 233-324 (1932); Hoffman, Grain Prices and the Futures Markets (USDA, Tech. Bull. No. $747,1941)$; Stevens, Relationship of Cash and Futures Prices, 155 Annals of the Academy, Part I, 82 (1931); Waite and Trelogan, Agricultural Market Prices 272 (2d ed., 1951). For a more theoretical British discussion precipitated by 2 Keynes, Treatise on Money, 142-44 (1930), see Kaldor, Speculation and Economic Stability, 7 Rev. of Econ. Studies, 1 (1939); Dow, A Theoretical Account of Futures Markets, ibid., at 185 (1940); Kaldor, Dow, and Hawtrey, A Symposium on the Theory of the Forward Market, ibid., at 196; Dow, The Inaccuracy of Expectations, 8 Economica (N.S.) 162 (1941).

Perhaps the leading American analyst is Holbrook Working. See Working, The Theory of Price of Storage, 39 Amer. Econ. Rev. 1254 (1947); Working, Inverse Carrying Charges on Futures Markets, 30 Jour. of Farm Econ. 1 (1948). On the futures market and the accuracy of expectations, see, Working, Quotations of Commodity Futures as Price Forecasts, 10 Econometrica 39 (1942).

11 Speculation on commodity futures has been justified for a variety of reasons: (1) Forecasting by speculators promotes short run stability of prices and the prompt and efficient adjustment of consumption to relatively fixed supplies. Hoffman, Futures Trading upon the Organized Commodity Markets 427 (1932). This and the conflicting Keynesian view are dis- 
There are two important methods of manipulating futures prices. The first, analogous to the usual method in securities, ${ }^{12}$ is the creation of such a state of misinformation in the market that others will be led to act in a manner which will be advantageous to the manipulator's position. ${ }^{13}$ This may be done either by fictitious transactions on the exchange, ${ }^{14}$ which create a false impression of

cussed and harmonized to some extent in Blau, Some Aspects of the Theory of Futures Trading, 12 Rev. of Econ. Studies 1, 23-27 (1944).

(2) The importance of the futures market as a medium for hedging, i.e., shifting market risks, has been recognized as paramount. See Howell, Analysis of Hedging and Other Operations in Grain Futures (1948) (on the extent to which hedging is not a perfect risk shifting device); Blau, Some Aspects of the Theory of Futures Trading, 12 Rev. of Econ. Studies 1, 2 (1944) (on the difference between the insurance principle of large numbers and risk bearing on commodities exchanges); Keynes, The Policy of Government Storage of Foodstuffs and Other Raw Materials, 48 Econ. Jour. 449 (1938); Larner, Economics of Control, c. 8 (1946); Johnson, Forward Prices for Agriculture (1947); Irwin, Middleman's Accumulations and Expectations in Marketing Farm Products, 29 Jour. of Farm Econ. 848 (1947) (on relative merits of the integrated firm, various systems of forward pricing, and other alternatives to the futures markets as means of transferring or reducing risks in the marketing of agricultural commodities).

Some of the benefits of hedging through the possibility of transferring risks are that it enables dealers to operate on smaller profit margins, resulting in savings to consumers, and facilitating financing of inventories. It has also been argued, more debatably, perhaps, that by minimizing the differences in capital between dealers, the trend toward concentration which has characterized other industries has been avoided. Hoffman, Grain Prices and the Futures Market 24 (USDA, Tech. Bull. No. 747, 1941). But it seems quite certain that effective monopoly control of a commodity is incompatible with futures trading in it. See Kulp, Possibilities of Organized Markets in Various Commodities, 155 Annals of the Academy, Part I, 176 (1931).

(3) The exchange acts as a center for continuous price registration and as a clearing house for information, making possible prompt response to changes in the cash market. For the relation of cash prices and futures quotations, see note 10 supra.

12 The relevant statutory provisions are 48 Stat. $888-91$, $\$ \S 9-10$ (1934), 15 U.S.C.A. $\$ \$ 78(i), 78(j)$ (1951). See generally, Loss, Securities Regulation, 883 et seq. (1951); Manipulation of the Stock Markets under the Securities Laws, 99 U. of Pa. L. Rev. 651 (1951).

${ }_{13}$ There is another sort of price phenomenon which, like that caused by spreading false information, depends on the mass psychology of the market. But it does not depend on the intent of a single person or on the concerted action of a small group. The trading on price movements which characterizes a large percentage of uninformed small speculators and also those more versed in the psychology of the market, intensifies and prolongs price trends beyond the point warranted by conditions in the market at large. For discussions of the illeffects of the practice, see Hoffman, Grain Prices and the Futures Market 41-59 (USDA, Tech. Bull. No. 747, 1941); Irwin, The Nature of Risk Assumption on the Organized Exchanges, 27 Am. Econ. Rev. 267, 270-77 (1937); Irwin, Middleman's Accumulations and Expectations of Marketing Farm Products, 29 Jour. of Farm Econ. 848 (1947). See also Keynes, General Theory of Employment, Interest, and Money 148-51 (1935); Hardy, Risk and Risk-Bearing 315 (1923).

14 Offsetting positions and fictitious transactions have been used for a variety of deceptive purposes: to create a false impression of market activity, avoid taking delivery, by brokers to deceive customers as to the condition of their accounts, but most frequently of all to reduce or avoid income tax liability. Report of the Administrator of the CEA 7 (1948). See in re Jean Goldwurm et al. 7 A.D. 265 (1948), and cf. Harold T. White (White, Francis M. Weld), 3 S.E.C. 466,510 (1938). The tax loopholes have since been closed. 17 C.F.R. 1.46 prohibits holding open both sides of a trader's offsetting position in the same future after the trades have 
market activity ${ }^{15}$ and lead to the registration of false prices, or by the spreading of rumors and unfounded information concerning the supply and demand conditions in the cash market or the intention of interests on the exchange to make or take delivery. ${ }^{16}$

The other common method of manipulation is the corner..$^{17}$ Although this term has been used to characterize a wide variety of situations, there appears as a common element in each of them the acquisition of a controlling long interest by means of which the cornerer is able to force the shorts to settle their contracts at an arbitrarily high price. ${ }^{18}$ In a well-known Sherman Act ${ }^{19}$ case, United States v.

been completed, and in Mem. 6243, 1948-1 CB44, modified by Mem. 6789, 1952-9 13808 (p. 16) (1953), the Bureau ruled that it would consider offsetting trades in the same commodity in the same future closed as of the moment the offsetting trade was made and that the gain is realized or the loss sustained at that time. Neither of these rules prevented the maintenance of long and short positions in two different markets. Hence, it was still possible, as in the case of stocks, to convert short term gains into long term gains by short sales. But this avenue of tax reduction is now closed as a result of the application of Int. Rev. Code $\$ 117(3)$ (B)(1) (short sales provision) to commodity futures. $3 \mathrm{CCH}$ Fed. Tax. Rep. I 864A, 865.0561, 873.05, 873.09, 873.11 (1953); 1 Rabkin and Johnson, Federal Income, Estate and Gift Taxation $\$ 34.07$ (4) (Supp. 7-1952). For an analysis of the tax cases involving futures transactions see 1 Rabkin and Johnson, ibid., at \$34.01(8) (Supp. 2-1953). For general discussions of the tax aspects of futures trading in relation to both "business" and "speculative" purposes, see Rich and Rippe, Tax Aspects of Commodity Futures Transactions with a Business Purpose, 2 Tax L. Rev. 541 (1947); Trading in Commodity Futures under the Federal Income Tax Statutes, 51 Yale L.J. 505 (1942).

${ }^{15}$ For an instance where fictitious transactions were used to create a false impression of market activity, see the complaint in Secretary of Agriculture v. Wexler, GFA Dkt. No. 9 (1935), where it was alleged that fictitious trades made by the respondent accounted for 50 to $93 \%$ of the total transactions in certain futures on certain days.

${ }^{16}$ For examples of this type of activity, see in re Reuben Earl McGuigan, 5 A.D. 249 (1946). Respondent, who under a variety of names advertised himself to be in the business of giving market advice to traders, would assume market positions and then send out telegrams advising purchases or sales which would favorably affect his position. In in re Irving Weiss \& Co., 7 A.D. 180 (1948), aff'd Irving Weiss \& Co. v. Brannan, 171 F. 2d 232 (C.A. 2d, 1948), registration of respondents as futures commission merchants was suspended for 10 days for failing to keep a true record of their customer, McGuigan, who explained to them that he was publishing a market report and wanted to prevent those who did not buy it from getting the same information through observation of his activities. See also in re Ralph W. Moore, 9 A.D. 1299 (1950), aff'd Moore v. Brannan, 191 F. 2d 775 (App. D.C., 1951), cert. denied, 342 U.S. 860 (1951). Respondent, who had a large long position in lard, evaded reporting requirements and circulated a document purporting to be a memo to the press endorsed by the Department of Agriculture stating that the government was about to make heavy lard purchases for export purposes when such was not the case. See also 7 FTC Report 258 (1926).

17 There is also the type of "corner" with which futures are in no way connected, "engrossing" the supply of a commodity, making it possible for the party in control to drive up the price to the consumer. 7 FTC Report 242 (1926).

${ }^{18}$ For various formulations see, Baer and Saxon, Commodity Exchanges and Futures Trading 82-83 (1949); U.S.D.A., C.E.A., A Primer of Trading in Commodity Futures (1937); Hubbard, Cotton and the Cotton Market 392 (1927); Smith, Organized Produce Markets 11213 (1922); Baer and Woodruff, Commodity Exchanges 146 (1926); Goldstein, Marketing: A Farmer's Problem 127 (1928); Emery, Speculation on the Stock and Produce Exchanges of the United States 173 (1896); Emery, Futures in the Grain Market, 9 Econ. Jour. 54 (1899); Kent 
Patten, ${ }^{20}$ involving a corner in cotton, the Supreme Court made a general formulation turning on the acquisition of control for the purpose of raising the price, and rejected the opportunity to enumerate the activities which would be the prerequisites of a corner. ${ }^{21}$ Although cornering as once practiced on the securities markets followed this general pattern, ${ }^{22}$ the problem of delivery on futures contracts introduces a technical difference which renders this concept inadequate. ${ }^{23}$ In the delivery month, especially in the last few days of trading, the cash and futures markets tend to merge ${ }^{24}$ because of the rights to make and take delivery ${ }^{25}$ a trader may plan or be tempted ${ }^{26}$ to take advantage of the situation by

v. Miltenberger, 13 Mo. App. 503, 506 (1883); Weld, The Marketing of Farm Products 32122 (1916); Brace, The Value of Organized Speculation 35 (1913).

${ }^{19} 26$ Stat. 209 (1890), as amended, 15 U.S.C.A. $\$ 2$ (1951).

${ }^{20} 226$ U.S. 525 (1911).

21 Ibid., at 539-40. 'CCounsel for the government expressly conceded that 'running a corner' consists, broadly speaking, in acquiring all or the dominant portion of a commodity with the purpose of artificially enhancing the price, 'one of the important features of which,' to use the language of the government's brief, 'is the purchase for future delivery, coupled with withholding from sale for a limited time'; and as this definition is in substantial accord with that given by lexicographers and juridical writers, we accept it for present purposes, although observing that not improbably in actual usage the expression includes modified means of obtaining substantially the same end" (emphasis added).

2 See, e.g., Sampson v. Shaw, 101 Mass. 145 (1869).

${ }^{23}$ The validity of this proposition, without the benefit of accompanying analysis, is recognized in Loss, Securities Regulation $626 \mathrm{n} .10$ (1951). It would seem that the court in General Foods Corp. v. Brannan, 170 F. 2d 220 (C.A. 7th, 1948), the only other corner case under the Commodity Exchange Act which got to a Court of Appeals, was unduly influenced by the sections on manipulation in the Securities Act, especially the one on permissive stabilization, although it was not expressly alluded to by the court. It has been argued that there is no comparable need for such activities on futures markets. See Manipulation of the Stock Markets under the Securities Laws, $99 \mathrm{U}$. of Pa. L. Rev. 651, 677-81 (1951). However, stoppage of trading and fixing settlement prices by the exchanges in situations where the market has collapsed, a corner attempt detected, and in other cases where it is necessary to "protect the market," is analagous to stabilization.

On the immunity of the exchanges from the Sherman Act for such stabilization, see Validity of Commodity Exchange Regulations under the Sherman Act, 16 Univ. Chi. L. Rev. 144 (1948). One rationale for the exemption of the exchanges from the anti-trust laws in this respect is their duty under Section 5(d), 7 U.S.C.A. 7(d) (1952), of the Commodity Exchange Act to prevent manipulation and cornering. See note 65 infra.

${ }^{24}$ In Chicago Board of Trade v. Olsen, 262 U.S. 1, 38 (1923), in which the constitutionality of the Grain Futures Act was upheld, the Court said, in response to contentions that "there is no relation between prices on the futures market and in the cash sales," that this was "hardly consistent with the affidavits the plaintiffs present from the leading economists ... [and] it is very reasonable to suppose that the one influences the other as the time of actual delivery of the futures approaches, when the prospect of heavy actual transactions at a certain fixed price must have a direct effect upon the cash prices in unfettered sales." See also 7 FTC Report 248 (1926), and 6 FTC Report 125 (1924).

"25 This was recognized in the Olsen case, 262 U.S. 1, 39 (1923), where the Court said, "The fact that a corner in grain is brought about by trading in futures shows the direct relation between cash prices and actual commerce on the one hand, and dealing in futures on the other, because a corner is not a monopoly of contracts only, it is a monopoly of the actual 
acquiring or exploiting a long position large relative to practically available supplies, possibly obtaining a large inventory of the cash commodity as well, all for the purpose of being able to demand arbitrarily high prices from the shorts for offsetting contracts. The delivery month which coincides with the end of the season, when deliverable supplies are small, is the favorite time for this type of operation..$^{27}$

The following activities are usual non-price indications of a corner. The cornerer often contrives various ways of lessening the supply of the commodity deliverable on long contracts. ${ }^{28}$ Although it is not necessary that deceit be involved, ${ }^{29}$ the cornering interest will not take pains to let it be known just how much of a concentrated long position he is developing and will probably adopt means to conceal the situation until it is too late to deliver. ${ }^{30}$ There will usually be congestion in the terminal market in which the exchange is located, with the cornerer having acquired all the deliverable supplies in the area in the course of his operations. ${ }^{31}$ An indication of the remoteness of the idea of delivery in the

supply of grain in commerce." It must be added, of course, that this monopoly is of a transitory nature.

28 "The long interest, no matter how built up, that allows itself to be tempted into exploiting the situation in a way to involve acute disturbance of the market becomes a comering interest." 7 FTC Report 244 (1926). See also, Hoffman, Grain Prices and the Futures Market 60 (1941).

There may be unintentional corners. Huebner, The Stock Market 339 n. 9 (1922). In 7 FTC Report 243 (1926), and Hoffman, Grain Prices and the Futures Market 66 (1941), situations are described in which the longs chose to stand for delivery because they wanted the cash supplies. In the former situation, which occurred in World War I, some of the Allied governments took large long positions with the result that the price of wheat on some exchanges rose sharply, but when it became apparent that wheat was unobtainable, those governments, interested only in obtaining wheat, released the shorts from their obligations.

${ }^{27}$ Hoffman, Grain Prices and the Futures Market 60 (USDA, Tech. Bull. No. 747, 1941).

${ }^{28}$ See Peto v. Howell, 101 F. 2d 353 (C.A. 7th, 1938) (shipped corn to Canada); Wright v. Cudahy, 168 Ill. 86, 48 N.E. 39 (1897) (corner in pork ribs; the pieces were cut in such a way as to make them not regular for delivery and then sold); Secretary of Agriculture v. Armour Grain Co., GFA Dkt. No. 1 (1926) (caused rye screenings to be stored in a public warehouse, rendering the whole load undeliverable). In General Foods Corp. v. Brannan, 170 F. 2d 220 (C.A. 7th, 1948), the government made various allegations which, although held not to be sustained by the "weight of the evidence," are examples of efforts to lessen the deliverable supply; i.e., bought long lines of the same commodity in another exchange and stood for delivery there, endeavored to have deliverable grain in boats at Chicago declared undeliverable if a duty was not paid, tried to merchandise its cash holdings by offering them to the government or to processors who would not let them get into the hands of speculators.

29 7 FTC Report 256-57 (1926). In Secretary of Agriculture v. Howell, GFA Dkt. No. 8 (1935), the Commodity Exchange Commission found that fraudulent and deceitful acts were evidence of intent but other elements charged made it clear that fraud and deceit are not necessary elements. Cf. General Foods Corp. v. Brannan, 170 F. 2d 220, 224 (C.A. 7th, 1948).

307 FTC Report 243, 257 (1926). When Cutten and Howell were carrying on their operations in 1931, they carried on 35 and 16 accounts, respectively, with 8 different firms. It is not surprising that administrative proceedings were not instituted until they had finished with their "attempts." See note 4 supra.

a 7 FTC Report 243, 244 (1926). 
minds of traders is the fact that in the usage of the trade it is often prima facie evidence of manipulative intent to carry large long lines into the delivery month. ${ }^{32}$

Although some of the notorious corners of the past involved control of the commercial visible supply in the United.States, ${ }^{33}$ it is generally recognized that a corner need not be of such scope and that there may be a corner in a local market. ${ }^{34}$ While the term "squeeze" is sometimes used to characterize such a corner of lesser extent, ${ }^{35}$ the terms have been used interchangeably. ${ }^{36}$ The squeeze is sometimes distinguished by the degree of price increase. The long interest, because of the relatively small supplies immediately available and the inertia of the shorts, is able to supply offsetting contracts at successively higher prices which, however, are not driven high enough to warrant the trouble and expense by the shorts of acquiring the cash commodity outside the terminal market in which the exchange is located..$^{37}$ This type of operation is usually the more successful because the problem of "burying the corpse" 38 is not as great as in the relatively tighter situation in which the shorts are driven to deliver large stocks from the outside, depressing the market in which the cornerer must dispose of the stocks acquired through his cornering activity. ${ }^{39}$ The congestion in

227 FTC Report 219 (1926).

${ }^{33}$ Leading examples are the Leiter corner in cotton, note 56 infra, and the Howell corner in corn, note 58 infra.

${ }^{34}$ Huebner, Corners, 4 Encyc. Soc. Sci. 408 (1937). This was recognized in United States v. Patten, 187 Fed. 664, 668 (S.D. N.Y., 1911), rev'd on other grounds 226 U.S. 525 (1911), where the Court said, "Broadly defined, a 'corner' is the securing of such control of the immediate supply of any product as to enable those operating the corner to arbitrarily advance the price of the product" (emphasis added).

35 Working, Price Relations between May and New-Crop Wheat Futures at Chicago since 1885, 10 Wheat Studies of the Food Research Institute $184 \mathrm{n} .1$ (1934); Baer and Saxon, Commodity Exchanges and Futures Trading 83 (1949); Baer and Woodruff, Commodity Exchanges 146 (1926).

${ }^{36}$ See, e.g., Emery, Speculation on the Stock and Produce Exchanges of the United States 175 (1896); Smith, Organized Produce Markets 112-16 (1922); Brace, The Value of Organized Speculation 105, 114 (1913); Weld, The Marketing of Farm Products 322 (1916). In the Report of the Sub Committee on Agriculture and Forestry on H.R. 6772, 74th Cong., 2d Sess. 124-25 (1936), "corner" and "squeeze" are used interchangeably in connection with the proposed provisions for a period after trading for delivery. In fact, this section of the Act mentions only "squeeze" and "market congestion" and does not use the term "corner." Section $5 a(4), 7$ U.S.C.A. $\$ 7 \mathrm{a}(4)$ (1952).

${ }^{37}$ Hubbard, Cotton and the Cotton Market 396 (1927); Smith, Organized Produce Markets 113 (1922).

${ }^{38}$ The term has its genesis in a statement of P. D. Armour who, when told that there was a large speculative short interest in December pork and was asked why he did not "corner" that delivery, replied, "To commit murder is very simple, the trouble is to bury the corpse." Hubbard, Cotton and Cotton Market 393 (1927).

${ }^{39}$ See also Emery, Speculation on the Stock and Produce Exchanges of the United States 175 (1896); 7 FTC Report 244 (1926). In the Howell case, for example, Howell made a profit of $\$ 270,214$ on his futures transactions from April 1 to July 31,1931 , but lost a total of $\$ 1,250,000$ in his subsequent efforts to get rid of his cash holdings. Chicago Journal of Commerce p. 3 , col. 1 (Jan. 19, 1935). 
the tighter situation aggravates the temporary and local derangement of prices ${ }^{40}$ which is one of the indications of a corner-markedly higher futures prices at the end of trading than in the days immediately following. ${ }^{41}$

A merchandiser familiar with handling the commodity may solve the problem of burying the corpse with a "spread." 22 By acquiring a short position in the next month's future before he may be forced to take delivery on his long position, he can limit losses by providing an outlet for the supplies acquired in the squeezed month. The profit on such an operation does not depend on a general rise in prices but on the ability to force a widening of the difference between the prices of the two futures. ${ }^{43}$ Such operations have often gone unnoticed because they do

${ }^{10} \mathrm{It}$ is recognized that the price aspects of a corner can come about in a few days. See, e.g., Shepherd, Marketing Farm Products 123 (1946); 7 FTC Report. 245-48 (1926); Smith, Organized Produce Markets 113 (1922); 5 FTC Report 323 (1920); Emery, Speculation on the Stock and Produce Exchanges of the United States 174 (1896).

41 "The statistical evidence of a corner-and also the evidence that it serves no good economic purpose-is the prevalence at the close of the delivery month of markedly higher prices than in the days following, especially for the grain futures, and also for cash grain, at the terminal market affected. The price of the grain is artificially enhanced because it is temporarily in extraordinary demand for the sole and only purpose of using it to meet future contracts." 5 FTC Report 323 (1920). See also, 7 FTC Report 245-48 (1926); Emery, Speculation on the Stock and Produce Exchanges of the United States 174 (1896); Smith, Organized Produce Markets 113 (1922).

42. For descriptions of the manipulative purposes to which spreads have been put, see 7 FTC Report 256 (1926); Cotton Prices Hearings before a Subcommittee of the Committee on Agriculture and Forestry, United States Senate, pursuant to Sen. Res. 142, 70th Cong., 1st Sess. 169, 203-14 (1928); Report of the Subcommittee of the Committee on Agriculture and Forestry on H.R. 6772, 74th Cong., 2d Sess. 124, 162 (1936). See 80 Cong. Rec. 7910, 74th Cong., 1st Sess. (1936).

43 "Squeezes are occasionally so handled that their financial success does not depend on effecting a price increase. Because the character of corners and squeezes is not generally well understood, such classes of abnormal market influence have sometimes, perhaps often, gone unrecognized or been regarded more lightly than they deserved by people not well versed in interpretation of the market.

"The indications are that successful corners or squeezes in wheat have sometimes been 'hedged.' For example, purchases of May wheat made as part of a plan for squeezing the market may be accompanied or shortly followed by sales of later deliveries, perhaps July. These sales of the later futures would not only provide an assured means of disposing of such deliveries on May contracts as may have to be accepted, but leave the 'squeezer' indifferent to the development of bearish price influences which may wholly offset the bullish effects of his operations in May wheat. With a comer or squeeze thus hedged, he need in nowise be concerned with the actual change in price of May wheat, since his profits depend merely on his ability to force a widening of the spread between May and July wheat of which he can take advantage. Indeed he may welcome a tendency toward general wheat price decline as an aid in obscuring the effects of his operation." Working, Price Relations Between May and New-Crop Wheat Futures in Chicago since 1885, 10 Wheat Studies of the Food Research Institute 184 (1934). "It is of the essence of the situation that the spreader is not coricerned with whether the general trend of prices is up or down. He is concerned with the widening or narrowing of the 'spread,' or the difference between two prices, and not with an upward or downward tendency that affects both contracts." 7 FTC Report 77 (1926). See also 7 FTC Report 245, 248 (1926); Working, Price Relations between July and September Wheat Futures at Chicago since 1885, 9 Wheat Studies of the Food Research Institute 211 (1933). For comparisons of the difference between "spreading" and "hedgings" see 7 FTC Report 
not necessarily result in movements contrary to the general trend of prices, and thus may be detected only in historically unusual price differentials between different futures, different markets, different grades, or different commodities. ${ }^{44}$

The short end of such a manipulative spread is similar to an operation conducted by elevator interests with short hedges against their inventory and forward purchases in the cash market. They often make large deliveries on the first day of the delivery month, driving the longs who do not wish to handle the commodity to sell hastily, depressing the price of the current future relative to that of the next month. The short interests are then able to transfer their hedges profitably and perhaps buy back the delivered cash supplies at favorable prices. ${ }^{45}$

Manipulation of futures prices is a burden on the public: the artificial prices thus created are quoted as a basis for prices in the cash market, ${ }^{46}$ successful hedging which depends on a reasonable parallelism between cash and futures prices is discouraged, ${ }^{47}$ the normal flow of consignments is disturbed, ${ }^{48}$ and speculators who supply the market liquidity necessary for hedging are subjected to risks unrelated to the supply and demand forces in the cash market. ${ }^{9}$ Moreover, a corner which fails because acquired stocks cannot be disposed of is as harmful to the public as one that is successful, since the loss to the public occurs in the artificial or manipulated price, not in the individual gains and losses. ${ }^{50}$

77 n. 13, 78, 33-68 (1926); 5 FTC Report 18 (1920); Emery, Speculation on the Stock and Produce Exchanges of the United States 159-79 (1896); Hoffman, The Hedging of Grain 23, 38 (1931); Federal Regulation of Commodity Futures Trading, 60 Yale L.J. 822, 825 (1951).

"Working, Price Relations between July and September Wheat Futures at Chicago since 1885, 9 Wheat Studies of the Food Research Institute 211 (1933). 7 FTC Report 77, 245, 248 (1926). See USDA, CEA, Investigation, op. cit. infra note 97.

${ }^{5}$ FTC Agricultural Income Inquiry 353 (1937); 7 FTC Report 81, 254, 291-92 (1926); 5 FTC Report 184 (1920); Hoffman, Future Trading upon Organized Commodity Markets 314 (1931).

45 See, e.g., Hoffman, Grain Prices and the Futures Market 30 (1941). For an instance where the price registration function of an exchange was abused through improper use of its facilities for trading in the cash commodity, see in re Zenith-Godley Co., Inc. and John MacClay, Jr., 6 A.D. 900 (1946). See also Report of the CEA (1947).

${ }^{47}$ Chicago Board of Trade v. Olsen, 262 U.S. 1, 39 (1923); 7 FTC Report 243, 248, 256 (1926); 5 FTC Report 323 (1920); Emery, Speculation on the Stock and Produce Exchanges of the United States 174 (1896); USDA, CEA, Investigation of the October 1949 Egg Futures Contract on the Chicago Mercantile Exchange 27 (1950); Report of the CEA 14 (1938); Testimony of Arthur R. Marsh, former President of the New York Cotton Exchange, in Cotton Prices, Hearings before a Subcommittee of the Committee on Agriculture and Forestry pursuant to Sen. Res. 142, 70th Cong., 1st Sess. 208-11 (1928); Smith, Organized Produce Markets 114 n. 2 (1922); Blau, Some Aspects of the Theory of Futures Trading, 12 Rev. of Econ. Studies 1,7 (1944).

${ }^{48}$ Chicago Board of Trade v. Olsen, 262 U.S. 1, 39 (1923).

49 Huebner, Corners, 4 Encyc. Soc. Sci. 409 (1931).

so 7 FTC Report 271 (1926). Of course the old saw has been applied to the effect that "any corner is a bad corner." Chicago Journal of Commerce, p. 3, col. 1 (January 19, 1935).

For a description of the ill effects of the attempted squeeze in the March 1953 onion future (an unregulated commodity) see The Packer, p. 1, col. 5 (April 4, 1953), in which it was claimed that the shorts, the longs, the dealers, the growers, and the public were all adversely affected. 
Although the standardized terms of the futures contract are necessary to a more perfect market, ${ }^{51}$ the foregoing analysis indicates that they have resulted in a susceptibility to manipulation. ${ }^{52}$ However, this has been mitigated by a number of factors. The dangers of manipulation are minimized by rapid communication and greatly improved storage facilities which widen in time and space the area from which supplies can be drawn. The provisions of the Commodity Exchange Act, ${ }^{53}$ which was aimed at the prevention of manipulation and other questionable market practices, ${ }^{54}$ have introduced many terms into the futures contract which give needed flexibility by facilitating the making and taking of delivery. ${ }^{55}$ Although big operators no longer dominate the exchanges as in the days of Hutchinson, Leiter, ${ }^{56}$ and Patten, ${ }^{57}$ or more recently, Cutten and

s1 The standardized elements reduce the risks to which one who takes delivery will be subject, thereby approximating the undifferentiated product which graces the pages of the economics textbooks. For this reason, only homogeneous commodities which are amenable to standardization are suitable for futures trading. See Blau, Some Aspects of the Theory of Futures Trading, 12 Rev. of Econ. Studies 1, 3 (1944).

It has also been pointed out that one of the reasons for the great amount of uninformed speculation on commodities exchanges is that the standardized methods of trading make it possible for a person to buy and sell without taking the time to learn all the special techniques necessary for one who speculates in unorganized untraded commodities through inventory speculation. Hardy, Risk and Risk-Bearing 215 (1923). On the ill effects of uninformed trading see note 13 supra.

${ }^{52}$ See Blau, op. cit. supra note 51.

${ }^{63}$ See note 3 supra.

s4 Mehl, Objectives of Federal Regulation of Commodities Exchanges, 21 Jour. of Farm Econ. 313 (1937); Mehl, Activities and Aims of the Commodity Exchange Authority (mimeo, 1937); Report of the CEA (1937); ibid. (1938); see also the subsequent yearly Reports which describe the activities of the Commodity Exchange Authority. For a recent description of the background and scope of the Act see Federal Regulation of Commodity Futures Trading, 60 Yale L.J. 822 (1951).

That aspect of the administration of the Act which relates to the regulation of the broker, commission merchant, customer relationship is not within the scope of this comment. A majority of the disciplinary proceedings under the Act have been in this area.

${ }^{65}$ The provisions of the Commodity Exchange Act recognize the social desirability of the possibility of making delivery on futures contracts. Nevertheless, they point up the fact that under modem conditions an unusually high ratio of deliveries is likely to be a pathological symptom. The animus of state anti-gambling legislation, which has relied on the small volume of deliveries as an indication of the useless character of futures trading, has been misdirected. Relatively minute quantities of deliveries indicate merely that a proper relation exists between cash prices and futures trading and that there is no point in making delivery. Irwin, Legal Status of Trading in Futures, 32 Ill. L. Rev. 155, 161 n. 20 (1937).

An illustration of the tension between the ideals of encouraging and discouraging delivery may be seen in Working, Price Relations between July and September Wheat Futures at Chicago since 1885, 9 Wheat Studies of the Food Research Institute 213 (1933) where it is said, "Unreasonable exercise of the legal privilege to take delivery of cash wheat may well be compared with unreasonable exercize of the legal privilege of depositors to demand payment of their total bank deposits in cash." Such intervention occurs in effect when the exchanges stop trading and fix settlement prices when an attempted corner or some other influence tends to demoralize the market. See note 17 supra.

${ }^{66}$ See Jeans, Trusts, Pools and Corners as Affecting Commerce and Industry: an Inquiry into the Principles and Recent Operations, Combinations and Syndicates to Limit Production and Increase Prices 161-74 (1894).

${ }^{57}$ United States v. Patten, 221 U.S. 525 (1913), rev'g 187 Fed. 664 (S.D. N.Y., 1911). 
Howell, ${ }^{58}$ not all attempts to influence futures prices have been prevented. Nevertheless, the strengthened provisions of the Act, ${ }^{59}$ including authority to limit speculative holdings and daily trading, ${ }^{60}$ to set reporting requirements when net positions reach amounts designated by the Secretary of Agriculture, ${ }^{61}$ to provide for extension of delivery periods ${ }^{62}$ and advance notice of intention to deliver ${ }^{63}$ and for the delivery of U.S. Standard grades which form the basis of difference systems, ${ }^{64}$ coupled with the possibility of administrative and criminal proceedings for their violation and for manipulation, cornering and spreading false information, ${ }^{65}$ have proved generally effective. The provisions for multiple delivery points by the exchanges and their increased vigilence enforced through the Commodity Exchange Authority's power to regulate the contract markets have also aided in the detection and prevention of artificial scarcity of deliverable supplies. ${ }^{66}$

58 For a description of the activities of Cutten and Howell, see Secretary of Agriculture v. Cutten, GFA Dkt. No. 7 (1935), and Secretary of Agriculture v. Howell, GFA Dkt. No. 8 (1936). See also Peto v. Howell, 101 F. 2d 353 (C.A. 7th, 1938) (triple damages action by a cornered short under the Sherman Act).

${ }^{59}$ For the background of the old Grain Futures Act, see the otherwise substantively correct note in Yale L. J., op. cit. supra note 54 , at 834 , which makes the misleading observation that the "only direct control over individual traders was a provision imposing criminal penalties for certain actions." Although in Wallace v. Cutten, 298 U.S. 229 (1936), the provisions providing for the denial of trading privileges were construed as not applicable to past activities, those sanctions had been applied in previous disciplinary proceedings on the theory that to do otherwise would cripple the administration of the Act. See, e.g., Secretary of Agriculture v. Ettinger \& Brand, GFA Dkt. No. 6 (1934).

${ }^{60}$ Section 4a, 7 U.S.C.A. $\S 6(a)(2)$ (1952). The rationale for this section that "excessive speculation" sometimes causes untoward fuctuations in prices, and that concentrated large scale buying and selling tend to intensify price trends. See 7 FTC Report 254, 258-59 (1926); Hoffman, Grain Prices and the Futures Market 41-60 (USDA, Tech. Bull. No. 747, 1941). For a discussion which throws grave doubt on the distinction by this section between hedging and speculation, exempting the former from the imposition of trading limits, see Working, Futures Trading and Hedging, $43 \mathrm{Am}$. Econ. Rev. 314 (1953). It is also recognized that speculative limits which make it impossible to build up large long lines and make traders hesitant in going up to the maximum permissible level, have a strong preventive effect in curbing manipulation and corners. CEA, USDA, Twenty-Five Years of Futures Trading under Federal Regulation 5 (1948). The latter reason seems to have been the chief animus behind the recent imposition of speculative trading limits on additional regulated commodities. See note 95 infra.

${ }^{61}$ Section 4i, 7 U.S.C.A. §6(i) (1952). Daily reporting requirements enable the Community Exchange Authority to check on the open interest in each market and thus prevent manipulation before it occurs.

${ }^{62}$ Section $5 \mathrm{a}(4), 7$ U.S.C.A. $\$ 7$ (a)(4) (1952) (facilitates delivery by the shorts by enabling them to deliver after the close of trading, lessening the chance of artificial scarcity at the terminal market at the crucial time).

${ }^{63}$ Section $5 a(5), 7$ U.S.C.A. $\$ 7$ (a)(5) (1952) (helps the longs when they are called upon to take delivery by preventing surprise, giving them time to make arrangements for payment and disposal of the stocks to be acquired).

${ }^{64}$ Section $5 a(6), 7$ U.S.C.A. $\$ 7(a)(6)$ (1952). For an explanation of difference systems see note 78 infra.

(s Sections 6(b), 9, 7 U.S.C.A. $\$ \S 9,13$ (1952).

${ }^{66}$ Under Sections 5(c) and (d), 7 U.S.C.A. $\$ \$ 7$ (c), (d) (1952), the "contract markets," i.e., exchanges, still have primary responsibility for the prevention of the dissemination of false 
II

"Weighing" the evidence, ${ }^{67}$ the court in the Greal Western case ${ }^{68}$ found that the respondents "had acquired and maintained a dominant and controlling long position in December, 1947 egg futures" on the Chicago Mercantile Exchange. ${ }^{69}$ They also obtained independent control of the available supply of cash eggs deliverable in satisfaction of December, 1947 futures contracts since out-oftown "storage" and all fresh eggs were not practically available because of "economic impediment[s]." The court said that the government's contention that prices were abnormal in the light of the "supply and demand situation"7I could not be sustained by the "weight of the evidence."72 Nevertheless it found that respondent's "control" of the cash and futures markets had "result[ed]" in price abnormalities: the large "spread" at the end of December trading by which December, 1947 futures prices were higher than those of January, 1948, and the fact that December futures and storage egg prices were high in relation to the to the price of fresh eggs. ${ }^{73}$ Intent to widen the spread between December and January futures, by which Great Western stood to profit because of a short posi-

information, manipulation and cornering which is enforced by the power of the Secretary of Agriculture to revoke their status as contract markets for not more than six months under Section 6(a), 7 U.S.C.A. \& 7(b) (1952). This provision, however, has never been used because of its drastic nature. Federal Regulation of Commodity Futures Trading, 60 Yale L.J. 822, 834 n. 62 (1951).

${ }^{67}$ Section 6(b), 7 U.S.C.A. $\$ 9$ (1952), provides for appeal to the circuit court in which the petitioner is doing business and that "the court shall have jurisdiction to affirm, to set aside, or modify the order of the Secretary of Agriculture, and the findings of the Secretary of Agriculture as to the facts, if supported by the weight of the evidence shall in like manner be conclusive" (emphasis added). This formulation of the standardization of judicial review is unique among the federal regulatory statutes. In the only corner case under the Act, General Foods Corp. v. Brannan, 170 F. 2 d 220 (C.A. 7th, 1948), the statutory criterion was construed to the effect that "the standard to be employed is something other than the 'substantial evidence' rule controlling in the review of administrative orders ... petitioners are entitled to have the order vacated unless the court concludes that it is sustained and to us that means the preponderance or greater weight." But in the Great Western case, although adverting to the standard as formulated in General Foods, the court went on to discuss the rule of the examiner as formulated in the case of Universal Camera v. NLRB, 190 F. 2d 429 (C.A. 2d, 1951). As finally interpreted, it "seem[ed]" to the court that its function was "something other than that of mechanically weighing the evidence to ascertain in which direction it preponderates; it is rather to review the record with the purpose of determining whether the finder of fact was justified, i.e., acted reasonably, in concluding that the evidence, including the demeanor of witnesses, the reasonable inferences drawn therefrom and other pertinent circumstances supported his findings. ..." After reviewing the evidence, the court concluded, "in short a review of the entire record is convincing that the greater weight of the evidence sustained the referee and the Judicial officer in their conclusions."

Bills introduced in both Houses in 1949, H.R. 4685 and S. 1751, would have amended the language of the statute to comply verbally with the "substantial evidence rule." For a recommendation to this effect, see Sellers, Administrative Procedure and Practice before the Department of Agriculture (CEA) 83 (1939).
${ }^{68} 201$ F. 2 d 476 (C.A. 7th, 1953).
7 Ibid., at 482 .
${ }^{69}$ Ibid., at 480 .
72 Ibid., at 482.
70 Ibid., at $480,481$.
${ }^{73}$ Ibid., at 483 . 
tion in January corresponding to its long position in December, ${ }^{74}$ was found solely on the basis of testimony by a government investigator concerning an interview with one of the respondents. ${ }^{75}$

As revealed by statistical tabulations interpreted by parol and by the testimony of trade witnesses, Great Western's operations in cash eggs and the December future went through three phases: (1) acquiring a relatively large long position and an equal short position in January; (2) maintaining its long position and decreasing the available supply of cash eggs; (3) closing out its long position in the last three days of trading.

From November 10 to 26 its long position increased by 198, while all other traders in the market increased their long positions by only 80 ; its holdings of the total open long contracts increased from $6.1 \%$ to $24.8 \%$ and at the end of this period and in the first days of December, when the December and January futures prices were within one cent of each other, Great Western acquired a corresponding short position in the January future, making the "spread." During the second phase, which continued until December 18, Great Western's long position in the December future remained approximately the same while 441 open contracts were liquidated by others. At the end of this period Great Western held 221 out of 336 open contracts, $65.8 \%$ of the total open on the Exchange. Then in the last three days of trading Great Western reduced its long position by 196, all others by 114, leaving 25 out of 26 , or $96.2 \%$ of the unliquidated contracts in the hands of Great Western at the close of trading in the December future on the twenty-third.

Great Western bought cash eggs in the beginning of December, acquiring ten carlots on the first and 71 on the third of the month. It sold 64 carlots in December, 30 for delivery in Chicago and 34 to out-of-town buyers and its New York office. Beginning four days before the end of trading, Great Western sold no cash eggs, although its cash inventory increased as it began taking delivery of cash eggs in satisfaction of December futures contracts. Great Western was substantially the only long to stand for delivery, being the ultimate stopper of 53 out of 55 carlots delivered both before and after the end of trading in satisfaction of December futures obligations. On December 31 Great Western owned 82 deliverable carlots which represented $97.5 \%$ of the deliverable eggs in Chicago warehouses, which with eggs owned by respondents in Detroit represented $66 \%$ of all the storage eggs in warehouses in Illinois, Indiana, Michigan, Ohio, and

74 The futures transactions in question relate to a "spread" operation conducted by Great Western between December, 1947 and January, 1948 egg futures contracts. The spread was set up when the prices of the two futures were very close to each other. The profit depended on the extent to which the prices widened after the position had been set up. For example, if a trader purchased December egg futures at 50 a dozen and sold January egg futures at $48 k$ a dozen, the initial spread between them would be $2 k$ a dozen. If the spread should widen the trader could close out his position at a profit because if the December futures price should rise, he could sell December contracts at more than he paid for his long position and if the January price falls he could buy long contracts at less than he paid for his shorts.

75201 F. 2 d 476, 484 (C.A. 7th, 1953). 
Wisconsin. ${ }^{76}$ Of these 82 carlots, 80 were delivered on its short position in the January future, with the rest of its short contracts being closed out at the lower prices prevailing in January.

Basic to the government's contention of a completed corner was the assumption that the supply of eggs practically available to the shorts for delivery in satisfaction of their December obligations consisted of "refrigerator" or "storage" eggs stored in Chicago. The respondent's argument was that since the Mercantile Exchange is a national market upon which more than one-half of the United States crop is traded, eggs all over the country should be considered as available because legally available by the rules of the Exchange. Par delivery, the "contract" or basic grade, consisted of "refrigerator eggs No. 2 U.S. Extras originally stored in an approved warehouse in Chicago and continuously maintained in such storage thereafter."77 There is no premium for the delivery of fresh eggs although in the fall and winter months the price of fresh eggs is usually higher than the price of refrigerator eggs. ${ }^{78}$ Witnesses for both the government and the respondent testified that it is usually uneconomical to deliver fresh eggs and that there are fresh egg deliveries only when there is a "tight" market.79

The delivery of refrigerator eggs in warehouses outside Chicago was subject to an allowance by the seller to the buyer of $\frac{3}{4} \xi$ per dozen, plus the necessity of paying higher freight charges from more distant points. ${ }^{80}$ The fact that eggs in other cities generally cost more than eggs in Chicago was revealed in the testimony of trade witnesses that it is a great disadvantage to deliver from outside points because higher prices can usually be obtained there. However, no statisti-

${ }^{76}$ Respondents argued that "percentages become meaningless" because December is the end of the season for storage eggs and December, 1947 storage egg stocks were the lowest on record. However, as has been pointed out, one of the earmarks of a corner is the acquisition of the deliverable supply and that the natural scarcity at the end of the season when deliverable supplies are low is a condition which enhances the facilitation of a corner. See note 27 supra.

${ }^{77}$ Rule 1405(f) of the Chicago Mercantile Exchange.

${ }^{78}$ Rule 1405(h) of the Chicago Mercantile Exchange. The rules with respect to this point are fundamentally different from the delivery rules existing on various exchanges with respect to other commodities, e.g., rye, cotton, wheat, com, oats, coffee, sugar, raw silk, rubber, hides, and copper, under which premiums are given to the shorts for above par deliveries. Some of the premiums are fixed at a level to encourage the delivery of par grade, but others are fixed to accurately put the buyer and seller on equal terms regardless of what grade is delivered. Of course, such differentials may be thrown out of line and not fulfill their function if there are abnormal spreads between deliverable grades. See Hoffman, Future Trading Upon the Organized Commodity Markets in the United States 277-305 (1932); Baer and Woodruff, Commodity Exchanges 13-16 (1926).

79 This parol evidence was corroborated by statistical evidence indicating that delivery of out-of-town and fresh eggs was comparatively rare in proportion to total deliveries which themselves accounted for less than $1 \%$ of the total contracts on the Exchange in the period 1941-47. Great Western Food Distributors, Inc. v. Benson, 201 F. 2d 476, 481 (C.A. 7th, 1953).

${ }^{80}$ Rule 1405(f) of the Chicago Mercantile Exchange. The history of trading in egg futures on the Exchange with no premiums for the delivery of fresh eggs has shown that provisions for outside delivery have not solved the problem. USDA, CEA, Investigation of the October 1949 Egg Futures Contract on the Chicago Mercantile Exchange 25 (1950). 
cal evidence was introduced. Also, delivery from warehouses outside Chicago could not be tendered after 9:00 A.M., December 22, although trading in December futures continued until the close of December 23, and delivery of fresh or Chicago storage eggs could be made thereafter for the remainder of the month. ${ }^{81}$ So-called "street stocks" or "floor stocks" of storage eggs were unavailable because they did not meet the requirement of continuous storage in an approved warehouse. To the extent that such stocks were composed of fresh eggs they were deliverable, but only if they were assembled in carlots containing the minimum number of individual lots of specified sizes (three of not less than one hundred) and placed in approved warehouses in Chicago or in refrigerator cars on track in Chicago at the expense of the person making delivery.

The government argued that "in order to prove manipulation in this case it is only necessary to prove that Great Western caused the price of refrigerator eggs in Chicago or December futures to be higher than they would have been if only the forces of supply and demand were operative." There was historical justification for the finding that the December, 1947-January, 1948 futures price spread was abnormally wide. Over the 15 year period from 1932 to 1948, the December future was generally at a premium of less than 1.5 over the following January future during the later weeks of trading in December. But during the last week of trading in the December, 1947 future the average spread was 5.94\% reaching $8.12 \dot{\xi}$ on the last day of trading. The former figure was more than three times comparable spreads in each of the ten years 1933-1941 and 1948, more than twice 1946 and substantially in excess of $1932 .{ }^{82}$ In response to Great Western's contention that comparisons of cents were misleading because of the lower price level prevailing in the 1930's, the government also presented figures measuring the December prices as percentages of the January prices. These figures showed that from 1932 to 1948 December closing prices averaged $103.3 \%$ of January, and that in December, 1947 this ratio was $112.4 \%$.

As a second indication of price abnormality, the government presented evidence indicating that the price of futures contracts and storage eggs was abnormally high in relation to the price of fresh eggs. Although the differential on December 11 was 6.85 per dozen, it was shown that from then on the price of fresh eggs fell while the price of the December future first fell slowly and then

81 Respondents agued that the shorts could have relied on the possibility that the price of fresh eggs would drop after the close of trading and before the end of the delivery month. They also contended that after December 23 there were sufficient Chicago storage eggs owned by persons other than Great Western. But the rules of the Exchange required traders positions closed out prior to the close of trading on December 23 unless the trader could satisfy the Clearing House Member that he would be able to make delivery. The government contended that under the circumstances of this case the corner ended on December 23 and that the availability of eggs after that date would be irrelevant to the proceedings. However, the evidence pertaining to after trading deliveries and Great Western's January operations is. relevant to show the business purpose of the whole operation.

8 There was no trading in 1942 and 1943 . The 1944 and 1945 spreads, $6.19 \&$ and 6.28 \& respectively, were rendered unrepresentative by ceiling prices on the cash commodity. These spreads equaled the difference between the ceiling prices for storage eggs in December and January, 
rose sharply during the last three days of trading, so that on the last trading day the price of the future was within $.5 \xi$ of the price of fresh eggs. In the period from 1932 to 1948 this difference was approximately 4 per dozen. On the basis of the fact that the cash price was almost identical with the current future at the end of trading, it was argued that the price of storage eggs was abnormal in relation to the price of fresh eggs also. ${ }^{83}$

In its reply brief and petition for rehearing, Great Western introduced figures on both these relations which showed that since the time of the facts in the case prices have behaved in a fashion unexplained by the government's theory of abnormality. The December, 1950-January, 1951 spread was 11.98k. And in four years out of five commencing with 1947, storage egg prices have been even higher than fresh egg prices, while in 1948 the December future closed lower than January and the premium of the fresh egg price over the future was greater than that in any year since $1932,11.75 \%$. The government's reply brief to the petition for rehearing made the argument that such facts were not part of the record and also that all the post-war December egg futures have been subject to manipulated and congested conditions. However, no analysis of the post-war December egg future situation has been published. Yet the court objected to the government's supply and demand analysis based on comparisons of current receipts with those in previous months because there was no analysis in terms of comparative market conditions. This it characterized as "fatal deficiencies in the government's theory."

Weighing all the above evidence rather mechanically, and omitting reference to post-war price conditions, the court found that Great Western had acquired control of both the futures and cash markets separately, resulting in price abnormalities, so that "all that remain[ed] to be proved to sustain the complaint was that this program was intentionally undertaken." ${ }^{84}$ This the court found in an ambiguous report by a Commodity Exchange Authority investigating officer concerning an interview with one of the respondents, which, however, if read with different emphasis, could be interpreted as a protestation of innocence and "business as usual" rather than as an admission of culpability. Although evidence of this type should not ignored it would have been more satisfactory for the determination of future cases in which such admissions might not be forthcoming, if the court had arrived at its conclusion through a causal analysis of Great Western's course of dealing. Objective circumstances are frequently afforded greater probative value than testimony by the offenders of "normal business purpose." 85

83 The government had to rely on this inference rather than the fact itself, because this figure, i.e., the price of storage eggs, had not been introduced into evidence and was not part of the record. However, see Dairy \& Poultry Yearbook 103 (1947) which substantiates the validity of the inference.

${ }^{84}$ Great Western Food Distributors, Inc. v. Benson, 201 F. 2d 476, 483 (C.A. 7th, 1953).

${ }^{85}$ See, e.g., under the Securities Act, Wright v. SEC, 112 F. 2d 89, 92, 93 (C.A. 2d, 1940); R. J. Koeppe \& Co. v. SEC, 95 F. 2d 550, 552 (C.A. 7th, 1938). See also Manipulation on the Stock Market under the Securities Laws, 99 U. of Pa. L. Rev. 651, 663 (1951). 
Such a finding of intent based on the facts of the case might be of the following nature. Although the respondents characterized their operation in terms of "economic hedges" it was in fact a "speculative spread." stood to profit through an upward movement of December futures prices relative to January. ${ }^{87}$ The fact that when it made its heavy purchases of futures in the first half of the month, it did not then acquire a dominant position, was not inconsistent with an attempt to corner. A long position which is relatively small in the early part of the month, if maintained, becomes a more dominant one later in the month as other longs drop out of the market. That Great Western was putting itself out of the market was shown by the fact that its "offers" to sell-75 to several hundred a day-found no takers while the other traders in the market were liquidating their long positions. In the last three days Great Western liquidated 180 of its long contracts as compared with 59 previously in the whole month. At the close of the last day's trading, Great Western was among those making the last and highest offers, indicating that it was pressuring prices on the upward side. Assuming that only Chicago storage eggs were practically deliverable, Great Western's long position, which exceeded the total stock of storage eggs in Chicago from December 2 to 22 put it in a position at the end of trading which required a substantial number of the shorts to come to it to offset their contracts. Its early month sales in the cash market-mostly to out-of-town buyers-reduced the supplies available to the shorts later in the month because once refrigerator eggs were out of storage they were rendered undeliverable by the rules of the Exchange.

In view of the artificially enhanced demand for storage eggs by the shortsshown by the large number of deliveries-Great Western could have disposed of its cash stocks acquired at December prices in December. Instead it chose to hold them for delivery on a portion of its short January position, all of which could have been closed out at a lesser price than that which it paid for the eggs it delivered, since historically, and this instance was no exception, January prices are lower than December's due to the influx of fresh eggs. The only rational explanation for Great Western's increasing its cash inventory in December and delivering at a loss in January is that Great Western was taking cash eggs off the market in order to squeeze the December shorts. And as market newsletters of the period show, ${ }^{88}$ the market was aware of the large cash supply

${ }^{88}$ For a detailed explanation of the difference see note 42 supra.

87 Under the Securities Act, if the respondent has an interest plus the required series of transactions, the burden of coming forward is shifted to the accused. Loss, Securities Regulation 905 (1951).

8 Although the reports received by the Commodity Exchange Authority are kept confidential and thus the trade does not have precise knowledge of the position of a trader, the market newsletters kept the trade informed of the general nature of the "big long interest's" operations. Uhlman Grain Co. Weekly Newsletter, December 15, 1947; James A. Bennett's Daily Market Letter, December 19, 1947. Of course the validity of these reports was impugned by the respondent, probably with some justification. See Hoffman, Futures Trading upon the Organized Commodity Markets of the United States 128 (1932). 
hanging over the January future which could not be disposed of elsewhere, which through the threat of delivery would depress the January futures price. This is common practice in a spread corner where the maximum profit is derived from differential elevation and depression of the current and deferred futures. ${ }^{89}$

Great Western's argument that the shorts could have closed out their positions by delivering out-of-town storage eggs prior to their undeliverability on the twenty-second, was in effect an argument that it would be legal to corner the shorts after that time. That this is what happened is shown by the fact that Great Western closed out 154 contracts on the twenty-second and third. Although the purpose of multiple delivery points and extension of delivery periods is to help prevent corners and squeezes, the legal availability of supplies more costly than Chicago storage eggs would merely tend to limit the extent to which prices could be raised before causing an avalanche of deliveries. In corner cases, as in those under the Sherman Act, "a monopolized resource seldom lacks substitutes; alternatives will not excuse monopolization." "socially desirable" to encourage deliveries, it is common knowledge that traders in futures do not wish to handle the cash commodity and that, in spite of the rules facilitating delivery, they hang on until it is too late. ${ }^{91}$

In the proceedings before the referee and the Judicial Officer the respondents claimed that they did not sell refrigerator eggs because there was no demand for them, yet they attempted to justify the high price in the latter part of December on the theory that there was a "strong firm market" situation for refrigerator eggs. But the refrigerator egg situation was quite weak after the tenth and eleventh because of the incoming supplies of fresh eggs. In the last three days of trading the price of storage eggs and futures contracts rose from $50.5 k$ to $53.5 k$, although storage eggs were not desired for consumption purposes because of the increasing supply of fresh eggs which were consequently dropping in price. That Great Western's activities were the cause of this abnormality was further substantiated by the fact that three days after the end of trading the price of cash refrigerator eggs dropped from $53.5 \xi$, the closing futures price, to $46 k$, an indication of the artificial demand for storage eggs for delivery on futures contracts.

All these circumstances would seem to indicate, then, that the respondent not only had a "dominant and controlling position" in the December future, but that it acquired this position knowingly and utilized its control intentionally to

${ }^{89}$ See note 42 supra.

${ }^{90}$ Gamco, Inc. v. Providence Fruit and Produce Building, 194 F. 2d 484, 487 (C.A. 1st, 1952), cert. den'd 344 U.S. 819 (1952).

"1 7 FTC Report 287, 292 (1926). "It is true that if the shorts would take the proper steps to secure the grain early enough in the delivery month, they could make delivery under existing circumstances, but anyone who has studied the market knows that the shorts live in hopes, even though they may die in despair, and they continue to hold short positions up to times when it becomes practically impossible for them to deliver, and the result is the extreme congestion we find in the squeeze situation." Statement of William Blair Stewart, Economist, Division of Analytical Surveys of the Commodity Exchange Administration, made at the Hearings of the Secretary of Agriculture, Hearing Dkt. CEA No. 2 (1937). See note 8 supra. 
put on a "squeeze," that is, to pressure December futures prices upward by means of its power over futures and storage eggs in Chicago. ${ }^{92}$ And although Great Western's operation did not result in ownership of all the storage eggs in Chicago prior to the end of trading, and therefore all the shorts were not prevented from making delivery, the facts above disclose a course of action which would seem to meet the trade usage and statutory definition of a corner in terms of the operational consequence of control.

III

As a result of an investigation of similar conditions in the October, 1949 egg future ${ }^{93}$ and evidence of post-war congestion in other commodities, ${ }^{94}$ speculative trading limits in additional commodities subject to regulation under the provisions of the Act have been promulgated by the Commodity Exchange Commission. ${ }^{95}$ They will effectively prevent individuals from building up commanding speculative positions in futures which are the first step on the way to a cornering expedition. Nevertheless, problems still remain: the difficulty, in spite of trading limits, of preventing and detecting concerted action by a group of traders, ${ }^{96}$ and

92 Respondents were experienced traders who knew what they were doing. This was circumstantially corroborated by the fact that the same respondents consented to an order suspending them for ten days for having attempted to corner the March, 1940 butter future. pecretary of Agriculture v. Great Western Distributors, Inc., CEA Dkt. No. 21 (1941).

${ }_{93}$ USDA, CEA, Investigation of the October, 1949 Egg Futures Contract on the Chicago Mercantile Exchange (1950). This future was characterized by an increase in the spread with the following November future which reached more than $7 \&$ on October 14 . At that time the Board of Governors of the Exchange stopped all trading pursuant to Emergency Rule 943 and required that all remaining contracts be fulfilled by delivery or settled at a specified price. Tbid., at 8-10. Both sides of the market expressed dissatisfaction with the market situation. Longs felt that the settlement price was too low or that the Exchange should have taken no action, leaving it to the conflicting interests to work it out. The shorts contended that the settlement price was too high but were convinced that the situation necessitated emergency action.

Criminal proceedings under both the Commodity Exchange Act and the Sherman Act have been brought against Great Western and its officers, along with another firm, for an alleged corner in the October, 1949 future. See 52 CR 238; 52 CR 239; 52 CR 315, on file in the District Court of the Northern District of Illinois, Eastern Div. The presentment of the Grand Jury also expressed dissatisfaction with the Chicago Mercantile Exchange for failing to take disciplinary action, pursuant to sections 400 and $401(\mathrm{~h})$ of its Rules, against the members of the Exchange who were responsible for the manipulated prices in the October future.

91 Report of the CEA 11 (1950); Report of the CEA 5 (1951).

25 Position and daily trading limits were first imposed before World War II on wheat, corn, oats, barley, and flaxseed, issued December 22, 1938, 3 F.R. 3146, as amended November 23, 1945, 10 F.R. 14363 (17 C.F.R. 150.1) closely followed by cotton issued August 26, 1940, amended April 2, 1947, 5 F.R. 3198, 12 F.R. 2287 (17 C.F.R. 150.2). There followed the imposition of limits on rye on November 23, 1945, 10 F.R. 14363 (14 C.F.R. 150.3); soybeans and eggs, August 23, 1951, 16 F.R. 8106-07 (17 C.F.R. 150.4, .5); cottonseed oil, soybean oil, and lard, January 16, 1953, 18 F.R. 443, 444, 445 (17 C.F.R. 150.6, .7, .8). For the rationales for trading limits, see note 60 supra.

$\$ 6$ In its latest complaint, CEA Dkt. No. 60 (1953), the government has charged thirteen companies and individuals with acting together to manipulate December 1952 egg futures prices on the Chicago Mercantile Exchange by means of a corner. See also Chicago Daily Tribune, Part 6, p. 7, c. 8 (Sept. 10, 1953). 
the possibility of improper reporting of futures positions. The latter is illustrated by evidence that a large short elevator interest, by improperly reporting its futures positions as "hedges," was able to depress United States oats prices in the spring of 1952. ${ }^{97}$ Moreover, the Act obviously cannot handle attempts to corner the futures markets in commodities under its jurisdiction. An example of such an attempt may be inferred from the price gyrations in the March, 1953 onion future on the Chicago Mercantile Exchange..$^{98}$ It seems to be the opinion within the trade that an abortive attempt to corner that contract was responsible. ${ }^{99}$

That the latter problem has been recognized is indicated by a bill introduced in both Houses in 1949 which provided for the extension of the jurisdiction of the Act to eleven additional named commodities and to any other "agricultural or forest product" that the Secretary of Agriculture, after notice and hearing finds subject to futures trading under conditions requiring regulation. ${ }^{100}$ The bill never reached the floor. The problems of concerted activity and improper reporting are of a nature not amenable to legislative solution, but depend on the efficiency with which the Act is administered.

97 USDA, CEA, Investigation of Importation of Oats from Canada 1951-52. A complaint has been issued against Cargill, Inc., one of the largest cash grain firms in the United States. CEA Dkt. No. 58 (1952). Though a leader in the industry, it has had a checkered career on the Board of Trade. Compare In re Cargill, Inc. v. Board of Trade of City of Chicago, CEA Dkt. No. 6 (1940), with Secretary of Agriculture v. Cargill, Inc., CEA Dkt. No. 11 (1940). See also Cargill v. Board of Trade of City of Chicago, 164 F. 2d 820 (C.A. 7th, 1947), noted in Validity of Commodity Exchange Regulations under the Sherman Act, 16 Univ. Chi. L. Rev. 144 (1948). See also Cargill v. Commodity Exchange Commission, 103 F. Supp. 992 (D.C. D.C., 1952).

${ }^{93}$ See The Packer, p. 1, col. 5 (Apr. 4, 1953).

99 The statement of W. J. Piowaty, "one of the biggest onion men in the country" and a member of the Chicago Mercantile Exchange, in The Packer, p. 1, col. 4 (Apr. 11, 1953), entitled "Grief in Onions--Speculation Plus Long Supplies Equals Trouble" drew a fine of $\$ 200$ and suspended revocation of trading privileges by the Mercantile Exchange. See The Packer, p. 1, col. 4 (June 6, 1953); Chicago Sun-Times, p. 58, col. 5 (June 10, 1953); Chicago Tribune, Part 3, p. 6, col. 3 (June 10, 1953). For a description of the March, 1953 onion debacle, see The Packer, p. 1, col. 3 (Apr. 4, 1953).

${ }^{100}$ H.R. 4685, S. 1751 (1949); Report of the Administrator of the Commodity Exchange Authority 9 (1949); 95 Cong. Rec. 5388, 81st Cong., 1st Sess. (1949). A more recent proposal by Representative King of Pennsylvania was to insert the word "onion" in Section 2(a), 7 U.S.C.A. $\$ 2$ (1952), "so that onions are added to the definition of the word 'commodity" for the purposes of said Act." H.R. 6435, 83d Cong., 1st Sess. (July 21, 1953). See Chicago Daily News, p. 24, col. 1 (July 28, 1953).

\section{EMPLOYEE STOCK OFFERINGS UNDER THE SECURITIES ACT-THE RALSTON PURINA CASE}

In 1951, the Ralston Purina Company offered to sell 10,000 shares of its common stock to approximately 500 of its 7,000 employees without complying with the registration requirements of Section 5 of the Securities Act of 1933. ${ }^{1}$ In an

148 Stat. 77 (1933), as amended, 15 U.S.C.A. $\$ 77$ (1951). 